Original Research Article

\title{
Dietary supplementation of Vitamin E and selenium on performance and oxidative stability of meat of broiler chickens in a hot climate
}

\author{
Deji Abiodun Ekunseitan' ${ }^{1}$, Azeez Olanrewaju Yusuf ${ }^{1}$, Oluwakemi Florence Ekunseitan², \\ Samuel Oluwaseunla Alao ${ }^{1}$, Adesewa Zainab Allinson ${ }^{1}$ \\ ${ }^{1}$ Department of Animal Production and Health, Federal University of Agriculture, PMB2240, Abeokuta, Ogun State, Nigeria \\ ${ }^{2}$ Department of Food Science and Technology, Federal University of Agriculture, Abeokuta, PMB 2240, Abeokuta, Ogun State, \\ Nigeria
}

\section{Correspondence to:}

D. A. Ekunseitan, Department of Animal Production and Health, Federal University of Agriculture, Abeokuta, Ogun State, Nigeria, e-mail: ekunseitanda@funaab.edu.ng

\begin{abstract}
With the increase in consumers' concern for safe food, it is highly imperative for livestock farmers to adopt feeding practices that enhance good health and high-quality products. A 49-day trial was conducted to ascertain effect of vitamin E and selenium (VE + Se) on performance, haematological indices and oxidative stability of chicken meat. A total of 150 Ross 7-day-old chicks were weighed and allotted to five treatments comprising dietary levels of $0 \mathrm{mg}$ $\mathrm{VE}+0 \mathrm{mg}$ SE (Control), $100 \mathrm{mg} \mathrm{VE}+0.05 \mathrm{mg}$ Se, $200 \mathrm{mg} \mathrm{VE}+0.1 \mathrm{mg}$ Se, $300 \mathrm{mg} \mathrm{VE}+0.15 \mathrm{mg}$ Se and $400 \mathrm{mg}$ $\mathrm{VE}+0.2 \mathrm{mg}$ Se per $\mathrm{kg}$ of feed in a completely randomised design. Feed and water were provided ad libitum. The data collected on performance, haematological indices and oxidative stability of meat were subjected to a one-way analysis of variance in a completely randomised design. Performance indices were significantly $(p<0.05)$ influenced by VE + Se supplementation. Mean daily live-weight gain (48.68 g/bird/day) was highest $(p<0.05)$ in the $400 \mathrm{mg}$ $\mathrm{VE}+0.2 \mathrm{mg}$ group. The mean daily feed intake (g/bird/day) was highest in birds fed the diet containing $200 \mathrm{mg}$ $\mathrm{VE}+0.1 \mathrm{mg}$. The least or best feed conversion ratio (FCR) was observed in the group fed $400 \mathrm{mg} \mathrm{VE}+0.2 \mathrm{mg} \mathrm{SE}$. Glutathione peroxidase (GSH-Px) increased as the level of VE + Se increased with the highest activity in $400 \mathrm{mg}$ $\mathrm{VE}+0.2 \mathrm{mg}$ Se group. The highest packed cell volume, haemoglobin and red blood cell values were observed in birds fed the diet containing $400 \mathrm{mg} \mathrm{VE}+0.20 \mathrm{mg}$ Se. In conclusion, to ensure good performance of the chickens and improved oxidative stability of chicken meat in hot climate, feeding broilers VE + SE at $400 \mathrm{mg}$ VE $+0.2 \mathrm{mg}$ Se is recommended.
\end{abstract}

Keywords: haematology indices; performance; feed intake; antioxidant enzymes; oxidative stability; broiler chickens

\section{INTRODUCTION}

The Nigerian broiler industry is continuously probing for ways to improve its product, shelf-life and quality in order to meet the demands of an increasingly consuming public and likewise proffer solution to effect of ever-changing climate in the tropics. The current trend of negativity in poultry production is climate change and its resultant effect causing extreme environmental temperature and resulting in health challenges (Wang et al., 2011). The synergy of these events results in oxidative stress in animals and concomitantly in their meat and its products. Several management and dietary modifications have been put forward to alleviate the negative effects of high environmental temperature. Nutritional manipulation remains one of the best ways of improving birds'

(C) AUTHORS 2021.

This work is licensed under the Creative Commons Attribution-NonCommercial-NoDerivs 4.0 License (https://creativecommons.org/licenses/by-nc-nd/4.0/) 
performance as well as ensuring the best meat quality. The use of vitamin E (VE) supplementation has found its usage in poultry production as it has been shown to provide antioxidant protection through immune system balancing especially in stress condition (Surai, 2002; Chae et al., 2005). It is recognised as a vital nutrient for growth, enhancement of immunity and health of all animal species; therefore, its use in the diet of broiler chickens is vital with respect to human health in terms of consuming a healthier poultry product (Galli et al., 2017). However, toxic effect of excessive use of VE has been rarely reported (Fellenberg and Speisky, 2006). Besides, extra dietary VE with combination with selenium (Se) has been identified as an effective antioxidant that prevents free radical's damage to tissues and stress in animals. It is well established that high VE content is required to improve the oxidative stability of broiler meat (Grau et al., 2001; Eder et al., 2005) but worthy of note that its excess in birds' diets has no negative consequence on health and similarly its deposition in meat samples since it demonstrates not just lipid protection (Mercier et al., 2001; Fellenberg and Speisky, 2006) but also protection of proteins in the meat from oxidation. Antioxidants, such as VE and Se perform a significant role in the protection of cells from ROS by reducing free radicals and preventing lipid peroxidation (Ghazi et al., 2012). Due to their vital role in cellular antioxidant defence system, their deficiencies will greatly affect growth, meat products and immunological functions (Niu et al., 2009a, b).

The quantity of VE converted from the bird's diet to meat depends on the amount consumed and the age of animal (Flachowsky et al.,2002). As poultry do not synthesise enough of this vitamin, therefore its dependency on dietary sources to provide the needed body requirements is great (Roch et al., 2010). In order to improve body antioxidant capacity, supplying antioxidants in the diet of birds such as VE and selenium (antioxidant enzyme precursors, and an essential component of glutathione peroxidase: GSH-Px) will have a positive impact on their health and performance. Therefore, their proper concentrations in the tissues will possibly result in the defence of biological systems against oxidative damage in birds as well as improve the quality of meat products. We hypothesised that extra dietary supplementation of vitamin E and selenium would influence the growth, haematological indices and oxidative stability of meat of birds. The present study was conducted to investigate the effect of additional levels of $\mathrm{VE}+\mathrm{Se}$ on growth performance and oxidative stability of meat in broilers in the tropics.

\section{MATERIALS AND METHODS}

The experiment was performed at the Poultry Unit of the Directorate of University Farms, Federal University of Agriculture, Abeokuta, Ogun State, Nigeria located on latitude $7^{\circ} 15^{\prime} \mathrm{N}$, longitude $3^{\circ} 26^{\prime} \mathrm{E}$ and $76 \mathrm{~m}$ above sea level. The experiment was conducted in March-April.

A total of 150 7-day-old Ross chicks were randomly allotted to five (5) dietary treatments, control containing no extra VE + Se, $100 \mathrm{mg} \mathrm{VE}+0.05 \mathrm{mg}$ Se, $200 \mathrm{mg}$ $\mathrm{VE}+0.10 \mathrm{mg}$ Se, $300 \mathrm{mg} \mathrm{VE}+0.15 \mathrm{mg}$ Se and $400 \mathrm{mg}$ $\mathrm{VE}+0.2 \mathrm{mg}$ Se per $\mathrm{kg}$ of feed. Each treatment group was further subdivided into three replicates of ten (10) birds each. The average weight of birds per treatment group was 81.44, 81.44, 80.92, 80.16 and $81.75 \mathrm{~g}$, respectively.

A straight diet (basal diet) was formulated as shown in Table 1, containing 20\% crude protein and metabolisable energy ( $\mathrm{kcal} / \mathrm{kg}$ ) of 2713.60 . The nutrient composition of the basal diet was determined using AOAC International (2005). The basal diet supplemented with the five (5) dietary VE + Se levels (no extra $\mathrm{VE}+\mathrm{Se}, 100 \mathrm{mg} \mathrm{VE}+0.05 \mathrm{mg} \mathrm{Se}, 200 \mathrm{mg}$ $\mathrm{VE}+0.10 \mathrm{mg}$ Se, $300 \mathrm{mg} \mathrm{VE}+0.15 \mathrm{mg}$ Se and $400 \mathrm{mg}$ $\mathrm{VE}+0.2 \mathrm{mg}$ Se per $\mathrm{kg}$ of feed) were fed to the birds throughout the 49-day feeding trial. Feed and water were provided to the birds ad libitum.

Table 1. Gross composition and nutrient level (\%) of basal diet

\begin{tabular}{lc}
\hline Ingredient & Amount (\%) \\
\hline Maize & 47.00 \\
Groundnut cake & 15.00 \\
Soybean meal & 23.00 \\
Wheat offal & 8.00 \\
Bone meal & 6.00 \\
Limestone & 3.00 \\
Lysine & 0.25 \\
Methionine & 0.25 \\
*Premix & 0.25 \\
Salt & 0.25 \\
\hline Total & 100 \\
\hline Determined Analysis & \\
\hline Metabolisable energy (kcal/kg) & 2713.00 \\
Protein (\%) & 20.00 \\
Crude fat (\%) & 3.90 \\
Crude fibre (\%) & 3.70 \\
\hline
\end{tabular}

*Premix provided per kilogram of diet: transretinyl acetate, $3.44 \mathrm{mg}$; cholecalciferol, $0.075 \mathrm{mg}$; menadione, $1.3 \mathrm{mg}$; thiamin, $2.2 \mathrm{mg}$; riboflavin, $8 \mathrm{mg}$; vitamin E; 11IU, nicotinamide, $40 \mathrm{mg}$; choline chloride, $400 \mathrm{mg}$; calcium pantothenate, $10 \mathrm{mg}$; pyridoxine $\cdot \mathrm{HCl}, 4 \mathrm{mg}$; biotin, $0.04 \mathrm{mg}$; folic acid, $1 \mathrm{mg}$; vitamin B12 (cobalamin), $0.013 \mathrm{mg}$; Fe (from ferrous sulfate), $80 \mathrm{mg}$; $\mathrm{Cu}$ (from copper sulphate), $8.0 \mathrm{mg}$; $\mathrm{Mn}$ (from manganese sulphate), $110 \mathrm{mg}$; Zn (from zinc oxide), $60 \mathrm{mg}$; I (from calcium iodate), $1.1 \mathrm{mg}$, Selenium; 0.23mg. 
All procedures performed were in agreement with ethical standards of the Institutional and/or National Research Committee and with the 1964 Helsinki declaration and its later amendments or comparable ethical standards. This experiment conformed to the ethical standards of the College of Animal Science and Livestock Production Committee on Animal Experimentation. The experiment begun after the proposal was ratified by the animal welfare expert in the college (ethical clearance number COLANIM/APH/UG/20130545).

Performance indices such as live-weight gain and feed consumption were recorded weekly whereas feed conversion ratio was computed. Whole blood was collected at 07:00 $\mathrm{h}$ on the $49^{\text {th }}$ day via jugular vein of the birds with the use of hypodermic needle. The blood samples for haematological profile were collected into sampling bottles pre-treated with EDTA (Ethylene Diamine Tetra acetic acid). Packed Cell Volume (PVC), Haemoglobin (Hb), Red Blood Cell (RBC), White Blood Cell (WBC), Differential white blood cell was determined using standard procedures: PCV was determined by microhematocrit method (Feldman et al., 2000), haemoglobin using the cyanmethaemoglobin method, RBC and WBC following the method of Brar et al. (2002) whereas the differential leucocyte counts were determined using blood films stained with Wright's stain (Benjamin, 1985). On the $49^{\text {th }}$ day of experiment, five birds from each replicate were selected, fasted for $12 \mathrm{~h}$ and then slaughtered via cervical dislocation and exsanguinated. Samples were excised from breast muscle region from each bird for analysis. The degree of lipid oxidation and stability of meat samples were monitored by measuring the MDA concentration (Rael et al., 2004) and Glutathione Peroxidase (GSH-Px) activity (Baker et al., 1990).

The obtained data were arranged in a one-way analysis of variance and analysed using the GLM procedure of the SAS/STAT module (SAS 9.0). Significances between treatment means were determined at $p<0.05$, Tukey's HSD test was used to separate treatment means. The data are presented as means and pooled standard error of means.

\section{RESULTS AND DISCUSSION}

The effect of dietary supplementation of VE + Se on the growth performance of broiler chicken is presented in Table 2. VE + Se had a significant $(p<.05)$ effect on all performance indices measured. It was observed that the final weight, total weight gain, daily weight gain, were highest in the $400 \mathrm{mg}$ VE $+0.2 \mathrm{mg}$ Se group. There was a significant increase in the final weight of birds as the level of $\mathrm{VE}+\mathrm{Se}$ increased with the best value in $400 \mathrm{mg} \mathrm{VE}+0.2 \mathrm{mg}$ Se group. Birds fed the diet containing $400 \mathrm{mg} \mathrm{VE}+0.2 \mathrm{mg}$ Se had the least and best feed conversion ratio (1.78) compared to the control and other VE + Se supplemented groups. This positive influence on growth indices in the study is in contrast with the report of Rey et al. (2015) who observed no changes in performance indices of turkeys fed a diet containing natural and synthetic dosages of VE $(40,80$ and $120 \mathrm{mg} / \mathrm{kg}$ ). However, our data are in agreement with the report of Chae et al. (2005) who reported higher weight gains in broilers with increasing levels of dietary VE up to $20 \mathrm{IU} / \mathrm{kg}$, as similar increasing trend in weight gain (Total weight gain, Daily weight Gain) was observed in the VE + Se groups (100, 200, 300 and $400 \mathrm{mg}$ ) compared to the control group. The improved weight gained in birds fed varying dietary levels of VE in combination with Se in diets in contrast to the control further attest to the antioxidant function of both in cell membrane as both plays an important role in growth, immunity and the fortification of biological system against oxidative damage in the live animal and its products (Cheng et al., 2016). Sole usage of Se in diets has been reported to have a beneficial effect on feed consumption and body weight gain (Paton et al., 2002) in birds. The synergistic effect of VE + Se resulted in a wide positive expression in the growth indices of the birds similar to Roch et al. (2000). The study,

Table 2. Effect of dietary vitamin $\mathrm{E}+$ Selenium on growth performance of broiler chickens

\begin{tabular}{|c|c|c|c|c|c|c|c|}
\hline Parameter & Control & $\begin{array}{l}100 \mathrm{mg} \mathrm{VE} \mathrm{+} \\
+0.05 \mathrm{mg} \mathrm{Se} \\
\end{array}$ & $\begin{array}{c}200 \mathrm{mg} \mathrm{VE}+ \\
+0.1 \mathrm{mg} \mathrm{Se} \\
\end{array}$ & $\begin{array}{l}300 \mathrm{mg} \mathrm{VE} \mathrm{+} \\
+0.15 \mathrm{mg} \mathrm{Se} \\
\end{array}$ & $\begin{array}{c}400 \mathrm{mg} \mathrm{VE} \mathrm{+} \\
+0.2 \mathrm{mg} \mathrm{Se} \\
\end{array}$ & SEM & P-Value \\
\hline Initial weight (g) & 81.44 & 81.44 & 80.92 & 80.16 & 81.75 & 0.25 & 0.3130 \\
\hline Final weight (g) & $2066.87^{b}$ & $2136.38^{b}$ & $2175.09^{b}$ & $2220.20^{\mathrm{b}}$ & $2467.03^{a}$ & 40.28 & 0.0010 \\
\hline Total weight gain (g/bird) & $1985.42^{\mathrm{b}}$ & $2055.13^{b}$ & $2148.17^{b}$ & $2140.04^{b}$ & $2385.28^{a}$ & 40.37 & 0.0020 \\
\hline Daily weight gain (g/bird/day) & $40.52^{\mathrm{b}}$ & $41.94^{b}$ & $43.84^{b}$ & $43.67^{b}$ & $48.68^{a}$ & 0.83 & 0.0020 \\
\hline Total feed intake (g/bird) & $4119.26^{b}$ & $4210.54^{b}$ & $4413.36^{\mathrm{a}}$ & $4132.08^{b}$ & $4240.41^{b}$ & 32.13 & 0.0030 \\
\hline Daily feed intake (g/bird/day) & $84.07^{\mathrm{b}}$ & $85.93^{b}$ & $90.07^{a}$ & $84.33^{b}$ & $86.54^{b}$ & 0.66 & 0.0030 \\
\hline Feed Conversion Ratio & $2.07^{\mathrm{a}}$ & $2.05^{\mathrm{a}}$ & $2.06^{\mathrm{a}}$ & $1.93^{\mathrm{a}}$ & $1.78^{\mathrm{b}}$ & 0.04 & 0.0050 \\
\hline
\end{tabular}

a,b; Values with different superscripts in the same row differ significantly $(p<0.05)$ SEM: Standard Error of the Mean. 
however, contradicts the report of Li et al. (2009) who opined no positive effect of sole supplementation of vitamin E in broiler diet up to $200 \mathrm{mg} / \mathrm{kg}$ on growth performance but rather a reduced lipid oxidation and drip loss, and Habibian et al. (2016) when birds raised in a thermoneutral and heat stressed unit were fed diets containing sole and mixed levels of VE $(0$, $125,250 \mathrm{mg} / \mathrm{kg}$ ) and Se $(0,0.5,1 \mathrm{mg} / \mathrm{kg})$. Although the total feed intake and daily feed intake did not follow a particular trend with birds in $200 \mathrm{mg} \mathrm{VE}+\mathrm{Se}$ consuming more compared to the control and other treatment groups, nonetheless birds fed on the diet containing $400 \mathrm{mg} \mathrm{VE}+$ Se had better efficiency in converting feed to flesh. The highest supplemental level of VE + Se in the diet improved the feed to gain of broiler chicken, a consequence of the better utilisation of nutrients and in agreement with earlier report of Villar et al. (2002) and Roch et al. (2000) who stated that feed efficiency (inverse of FCR) increased significantly with their increased supplementation. Similarly, Sahin and Kucuk (2001) also observed a positive effect on performance indices resulting in improvement in weight gain, feed intake and feed conversion ratio of Japanese quail reared on a diet supplemented with $250 \mathrm{mg}$ VE + $0.2 \mathrm{mg} / \mathrm{kg}$ Se. In addition, Kennedy et al. (1992) observed an increase in productivity as a result of improvements in both feed conversion rate (FCR) and weight gain. The higher capacity of the antioxidant system supported by the higher dietary combination of VE and Se level in diet may suggest a better nutrient utilisation observed in this study as sole usage of Se studied by Edens et al. (2000) and Yoon et al. (2007) revealed no noticeable effect on body weight, feed intake and feed conversion ratio.

The haematological indices of broiler chickens fed onthe diet containing vitamin $\mathrm{E}$ is presented in Table 3. $\mathrm{PCV}, \mathrm{Hb}$ and RBC counts were significantly $(p<0.05)$ affected by vitamin E supplementation. Significantly highest values of PCV (31.00\%, 30.67\%), haemoglobin $(103.00 \mathrm{~g} / \mathrm{l}, \quad 101.30 \mathrm{~g} / \mathrm{l})$ and $\mathrm{RBC}\left(2.57 \times 10^{12} / \mathrm{l}\right.$, $2.60 \times 10^{12} / \mathrm{l}$ ) were recorded in birds in the control group and birds fed the diet containing the highest dietary inclusion of VE + Se. Haematological indices play a great role in practical husbandry as they reflect biological responses of the animals to external and internal stimuli (Ahmad et al., 2003; Ekunseitan et al., 2017). Dietary VE supplementation, however, is known to have a direct effect on rate of blood synthesis (red blood and white blood cells formation) as observed at the highest supplementation level when compared to the control group. Increase in blood synthesis resulted in higher PCV, as an increase in PCV is linked with the increase in total red blood cells count (Al-Daraji et al., 2012). PCV is the indirect way of assessing values of red blood cells in circulation as it indicates the percentage of RBC in the blood (Purves et al., 2003), and used as a simple screening test for anaemia (Bashar et al., 2010). $\mathrm{Hb}$ concentration was similar and significantly $(p<0.05)$ highest in the control and $400 \mathrm{mg}$ VE + $0.2 \mathrm{mg}$ Se group; this may be attributed to a possible combined effect $(\mathrm{VE}+\mathrm{Se})$ on the process of erythropoiesis as a response to environmental changes. Similar observations were reported by Tayeb and Qader (2012), nmely, that inclusion of $\mathrm{VE}+\mathrm{Se}$ at moderate levels up to $150 \mathrm{mg}$ $\mathrm{VE}+0.45 \mathrm{mg}$ Se significantly improved haemoglobin concentrations.

The non-significantly different white blood cell count and its differential counts observed in this study is in agreement with Akbari et al. (2008) who detailed a similar effect of VE when supplemented in diets on the percentage of white blood cell counts and differentials (monocytes, lymphocytes and heterophils) and Habibian et al. (2014) with sole Se supplementation. This result, however, negates the report by Puthpongsiriporn et al. (2001) who postulated that lymphocyte proliferation is a result of higher

Table 3. Haematological indices of broiler chickens fed a diet containing Vitamin E + Selenium

\begin{tabular}{|c|c|c|c|c|c|c|c|}
\hline Parameter & Control & $\begin{array}{l}100 \mathrm{mg} \mathrm{VE}+ \\
+0.05 \mathrm{mg} \mathrm{Se}\end{array}$ & $\begin{array}{l}200 \mathrm{mg} \mathrm{VE}+ \\
+0.1 \mathrm{mg} \mathrm{Se}\end{array}$ & $\begin{array}{l}300 \mathrm{mg} \mathrm{VE}+ \\
+0.15 \mathrm{mg} \mathrm{Se}\end{array}$ & $\begin{array}{l}400 \mathrm{mg} \mathrm{VE}+ \\
+0.2 \mathrm{mg} \mathrm{Se}\end{array}$ & SEM & P-Value \\
\hline Packed cell volume (\%) & $31.00^{\mathrm{a}}$ & $28.33^{b}$ & $26.67^{c}$ & $27.00^{b}$ & $30.67^{a}$ & 0.59 & 0.021 \\
\hline Haemoglobin (g/l) & $103.00^{\mathrm{a}}$ & $95.30^{\mathrm{b}}$ & $89.00^{c}$ & $91.00^{\mathrm{b}}$ & $101.30^{\mathrm{a}}$ & 1.89 & 0.037 \\
\hline Red blood cell $\left(\times 10^{12} / \mathrm{l}\right)$ & $2.57^{\mathrm{a}}$ & $2.20^{\mathrm{b}}$ & $2.00^{c}$ & $2.27^{\mathrm{b}}$ & $2.60^{\mathrm{a}}$ & 0.08 & 0.050 \\
\hline White blood cell $\left(\times 10^{9} / \mathrm{l}\right)$ & 11.13 & 12.27 & 11.00 & 11.43 & 11.97 & 0.42 & 0.891 \\
\hline Heterophil (\%) & 32.67 & 24.00 & 32.00 & 38.00 & 32.00 & 1.72 & 0.126 \\
\hline Lymphocyte (\%) & 66.67 & 74.00 & 66.67 & 61.33 & 66.67 & 2.60 & 0.188 \\
\hline Eosinophil (\%) & 0.33 & 0.33 & 0.33 & 0.00 & 0.67 & 0.13 & 0.655 \\
\hline Basophil (\%) & 0.00 & 0.33 & 0.33 & 0.00 & 0.00 & 0.09 & 0.580 \\
\hline Monocyte (\%) & 0.67 & 1.33 & 0.67 & 0.67 & 0.67 & 0.22 & 0.081 \\
\hline
\end{tabular}

$\overline{a, b, c}:$ Means with different superscript along the same rows are significantly different $(\mathrm{p}<0.05)$ SEM: Standard Error of the Mean 


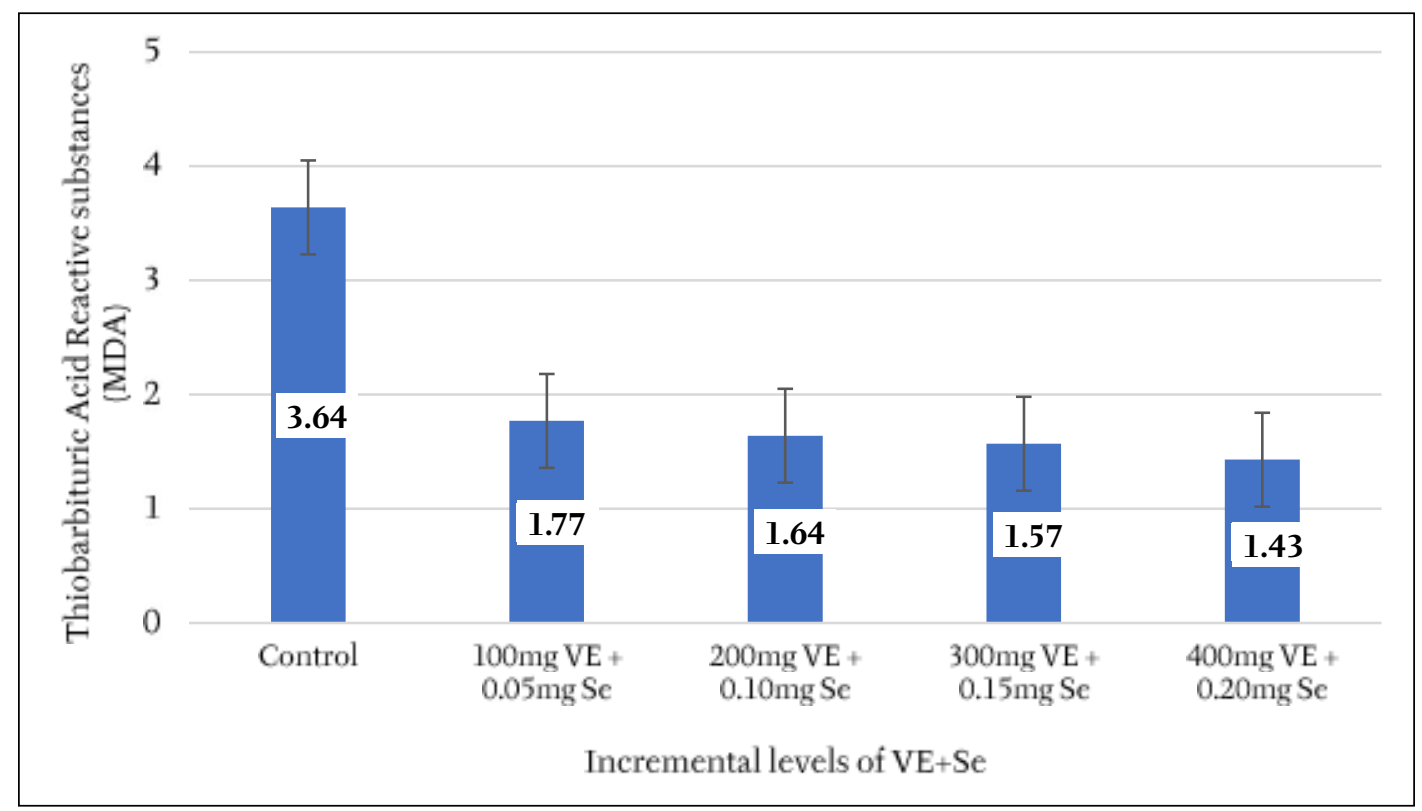

Figure 1. Effect of $\mathrm{VE}+\mathrm{Se}$ on thiobarbituric acid reactive substance of broiler chicken meat

dietary vitamin $\mathrm{E}$ supplementation in diets but the possible synergistic effect by VE + Se may account for alterations of the results obtained in this study. This non-significant observation in the current study aligns with Habibian et al. (2014) who reported no positive interaction of $\mathrm{VE}+\mathrm{Se}$ on percentages of heterophil and lymphocyte counts and $\mathrm{H} / \mathrm{L}$ ratio compared to the increase observed in sole supplementation of VE on lymphocytes $\mathrm{H} / \mathrm{L}$ ratio in the same study.

The effect of varying levels of vitamin $\mathrm{E}$ on malondialdehyde (MDA) in broiler chicken meat is presented in Figure 1. Increasing VE + Se in diet of birds decreased meat MDA levels with the least obtained birds fed the diet containing $400 \mathrm{mg} \mathrm{VE}+0.2 \mathrm{mg}$ Se. Poultry meat is prone to oxidative reactions due to the presence of unsaturated muscle lipids (Estévez, 2015), which are chemically unstable and readily undergo oxidative reactions, resulting in their spoilage. This research indicates that dietary $\mathrm{VE}+$ Se increased the oxidative stability of the meat by lowering the MDA. The resilient activity observed from meat sampled affirm the protective action of $\mathrm{VE}+$ Se since broilers meat and its products are prone to oxidative stress as a consequence of targeted genetic selection for broader breast muscles, rapid growth rate (Fellenberg and Speisky, 2006; Sihvo et al., 2013) and presence of unsaturated muscle lipids during meat aging (Estévez, 2015). Unsaturated fatty acids are chemically unstable food components and freely undergo oxidative reactions resulting in their subsequent spoilage during storage. The continuous inhibition and reduction of TBARS values in meat tissue could be due to a protective effect exhibited by VE + Se on the lipid bilayers in the meat resulting in the stability and oxidative protection. Each nutrient exhibits a different anti-oxidative activity in the biological system: VE inhibits peroxide formation, whereas Se as a component of seleno-enzyme GSH-Px destroys peroxides (Young et al., 2003; Wang et al., 2011). The observed activities differ from those reported by Habibian et al. (2016) who detected no effect on lipid oxidation of the breast meat when VE and Se were used separately, but observed a positive synergistic action similar to that in current study when both were added at $125 \mathrm{mg} / \mathrm{kg} \mathrm{VE}$ and $1 \mathrm{mg} / \mathrm{kg}$ Se resulting in a significant reduction in MDA. The antioxidant function of vitamin $\mathrm{E}$ is therefore closely related and synergistic with the functional role of Se.

The effects of varying levels of vitamin $\mathrm{E}$ on antioxidant status of broiler meat are presented in Figure 2. There was a continuous increase in GSH-Px activity as the level of the supplementation of $\mathrm{VE}+\mathrm{Se}$ in diets increased with the highest activity observed in the $400 \mathrm{mg} \mathrm{VE}+0.2 \mathrm{mg}$ Se. This is in variance with the report of Voljc et al. (2011) who observed no effect in meat muscles. This variation may be a result of modulating GSH-Px activity in a complex manner resulting in physiological regulation of antioxidant defences in the cell under stress and consequent expression in the meat muscle. A reduced antioxidant enzyme activity contributes to reduced oxidative stability of the muscle leading to spoilage while the increase in its activity allows it to exhibit its defence system in cellular antioxidant protection of organism from oxidative damage. GSH-Px plays a vital role in 


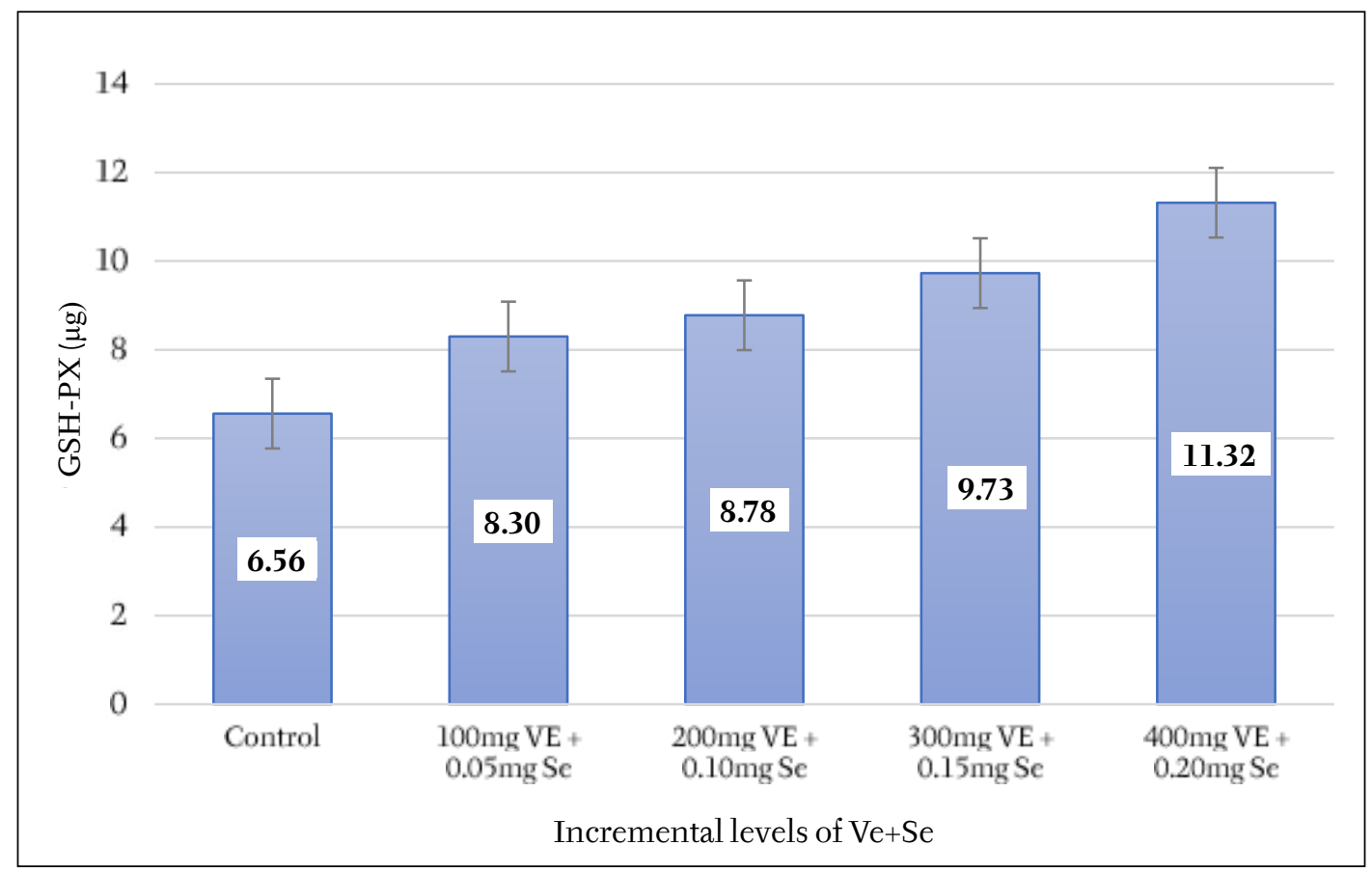

Figure 2. Effect of $\mathrm{VE}+\mathrm{Se}$ on antioxidant profile of thigh meat of broiler chickens

the antioxidant defence system and it is involved in cellular antioxidant protection, an enzyme family with peroxidase activity which helps to protect the organism from oxidative damage. The resultant inverse relationship between the enzyme-activity and MDA production clearly indicates the important role of GSH-Px as an antioxidant defence system which helps rid-off or suppress concentration of MDA in the meat since a higher quantity of lipids will deteriorate the meat tissue. The observation in the present study is in contrast to Maraschiello et al. (1999) who observed a reduced enzyme activity in tissues of broilers supplemented with R-tocopherol in diets. A positive relationship has been postulated to exist between VE, Se and GSH-Px as antioxidant defences in biological membranes in muscles of chickens and thus play a precise part in the regulation of other vital functions. Surai and Dvorska (2002) observed a higher activity of GSH-Px in muscles of breeder chickens which was connected to supplemental organic Se in combination with VE similar to the report of Özkan et al. (2007).

\section{CONCLUSION}

The results of this study indicate that it is possible to improve the production potentials and likewise the quality of meat of broiler chickens through dietary supplementation of both VE and Se. The recommended dietary level is $400 \mathrm{mg} \mathrm{VE}+0.2 \mathrm{mg}$ Se for optimal performance of broiler chickens under the hot climate conditions.

\section{CONFLICT OF INTEREST}

The authors declared no conflicts of interest with respect to research, authorship and publication of this article.

\section{REFERENCES}

Al-Daraji H. J., Al-Mashadani H. A., Al-hassani A. S., Mirza H. A., Al-Hayani W. K. (2012): The influence of parsley (Petroselinum crispum) as feed additive on haematological traits of local Iraqi geese. Advances in Nutrition Research 1: 1-5.

AOAC International (2005): Official methods of analysis of AOAC International, 17th $e d$. Association of Official Analytical Chemists.

Ahmad I., Gohar A., Ahmad N., Ahmad M. (2003): Haematological profile in cyclic, non-cyclic and endometritic cross-bred cattle. International Journal Agriculture and Biology 5: 332-334.

Akbari M. R., Kermanshahi H., Moghaddam N. (2008): Effect of wheat-soybean meal-based diet supplementation with Vitamin A, Vitamin E and Zinc on blood cells, organ weights and humoral immune response in broiler chickens. Journal of Animal Veterinary Advances7: 297-304.

Baker M. A, Cerniglia G. J., Zaman A. (1990): Microtiter plate assay for the measurement of glutathione and glutathione disulfide in large numbers of biological samples. Analytical Biochemistry 190: 360-365.

Bashar Y., Tukur M., Sekoni A., Hassan W. (2010): Nutrient retention and haematological indices of 
broiler starters fed lablab seed meal as the source of protein. Nigerian Journal of Basic Applied Science 18: 285-291.

Benjamin M. M. (1985): Outline of veterinary clinical pathology. $3^{\text {rd }}$ Ed. The Iowa State University Press, Ames.

Brar R. S., Sandhu H. S., Singh A. (2002): Veterinary clinical diagnosis by laboratory methods. $1^{\text {st }}$ Ed. Kalyani Publishers, New Delhi.

Chae B. J., Lohakare J. D., Choi J. Y., Han K. N., Yong J. S., Won H. K., Park Y. H., Hahn T. W. (2005): The efficacy of vitamin $\mathrm{E}$ - polyethylene glycol complex on growth performance, chicken meat quality and immunity in broilers. Journal of Animal and Feed Sciences 14: 125-138.

Cheng K., Song Z. H., Zheng X.C., Zhang H., Zhang J. F., Zhang L. L., Zhou Y. M., Wang T. (2017): Effects of dietary vitamin $\mathrm{E}$ type on the growth performance and antioxidant capacity in cyclophosphamide immunosuppressed broilers. Poultry Science 96: 1159-1166.

Edens F. W., Carter T. A., Parkhurst T. C. R., Sefton A. E. (2000): Effect of selenium source and litter type on broiler feathering. Journal of Applied Poultry Research 9: 407-413.

Eder K., Grunthal G., Kluge H., Hirche F., Spilke J., Brandsch C. (2005): Concentrations of cholesterol oxidation products in raw, heat-processed and frozen-stored meat of broiler chickens fed diets differing in the type of fat and vitamin $\mathrm{E}$ concentrations. British Journal of Nutrition 93: 633-643.

Ekunseitan D. A., Abiola S. S., Oluwatosin O. O., Sogunle O. M., Adeleye O. O., Egbeyale L. T., Iyasere O. S. (2017): Health status of laying birds administered extracts of Lagenaria breviflora managed under two housing systems. Canadian Journal of Animal Science 97: 154-164.

Estévez M. (2015): Oxidative damage to poultry: from farm to fork. Poultry Science 94: 1368-1378.

Feldman B. F., Zinkl J. G., Jain N. C., Schalm O. W. (2000): Schalm's Veterinary Hematology. $5^{\text {th }}$ Ed. Lippincott Williams and Wilkins, Philadelphia.

Fellenberg M. A., Speisky H. (2006): Antioxidants: their effects on broiler oxidative stress and its meat oxidative stability. World Poultry Science Journal 62: 53-70.

Flachowsky G., Engelman D., Sunder A., Halle I., Sallmann H. P. (2002): Eggs and poultry meat as tocopherol sources in dependence on tocopherol supplementation of poultry diets. Food Research International 35: 239-243.
Galli F., Azzi A., Birringer M., Cook-Mills J. M., Eggersdorfer M., Frank J., Cruciani G., Lorkowski S., Özer N. K. (2017): Vitamin E: Emerging aspects and new directions. Free Radical Biology and Medicine 102: 16-36.

Ghazi S., Habibiyan M., Moeini M. M., Abdolmohammadi A. R. (2012): Effects of dietary selenium, vitamin $\mathrm{E}$, and their combination on growth, serum metabolites, and antioxidant defense system in skeletal muscle of broilers under heat stress. Biological Trace Element Research 148: 322-330.

Grau A., Guardiola F., Grimpa S., Barroeta A. C., Codony R. (2001): Oxidative stability of dark chicken meat through frozen storage: influence of dietary fat and alpha-tocopherol and ascorbic acid supplementation. Poultry Science 80: 1630-1642.

Habibian M., Ghazi S., Mehdi Moeini M., Abdolmohammadi A. (2014): Effects of dietary selenium and vitamin $\mathrm{E}$ on immune response and biological blood parameters of broilers reared under thermoneutral or heat stress conditions. International Journal of Biometeorology 58: 741-752.

Habibian M., Ghazi S., Mehdi M. (2016): Effects of Dietary Selenium and Vitamin E on Growth Performance, Meat Yield, and Selenium Content and Lipid Oxidation of Breast Meat of Broilers Reared Under Heat Stress Moeini. Biological Trace Element Research 169: 142-152.

Kennedy D. G., Rice D. A., Bruce D. W., Goodall E. A., McIlroy S.G. (1992): Economic effects of increased vitamin E supplementation of broiler diets on commercial broiler production. British Poultry Science 33: 1015-1023.

Li W. J., Zhao G. P., Chen J. L., Zheng M. Q., Wen J. (2009): Influence of dietary vitamin E supplementation on meat quality traits and gene expression related to lipid metabolism in the Beijing-you chicken. British Poultry Science 50: 188-198.

Maraschiello C., Esteve E., Garcia-Regueiro J. A. (1998): Cholesterol oxidation in meat from chicken fed alpha-tocopherol and $\beta$-carotene-supplemented diets with different unsaturation grades. Lipids 33: 317-507.

Mercier Y., Gatellier P., Vincent A., Renerre M. (2001), Lipid and protein oxidation in microsomal fraction from turkeys: influence of dietary fat and vitamin $\mathrm{E}$ supplementation. Meat Science 58: 125-134.

Niu Z. Y., Liu F. Z., Yan Q. L., Li L. (2009a): Effects of different levels of selenium on growth performance 
and immunocompetence of broilers under heat stress. Archives of Animal Nutrition 63: 56-65.

Niu Z. Y., Liu F. Z., Yan Q. L., Li W. C. (2009b): Effects of different levels of vitamin $\mathrm{E}$ on growth performance and immune responses of broilers under heat stress. Poultry Science 88: 2101-2107.

Özkan S., Malayoğlu H. B., Yalçin S., Karadaş F., Koçtürk S., Çabuk M., Ergül M. (2007): Dietary vitamin $\mathrm{E}$ ( $\alpha$-tocopherol acetate) and selenium supplementation from different sources: performance, ascites-related variables and antioxidant status in broilers reared at low and optimum temperatures. British Poultry Science 48: 580-593.

Paton N. D., Cantor A. H., Pescatore A. J., Ford M. J., Smith C. A. (2002): The effect of dietary selenium source and level on the uptake of selenium by developing chick embryos. Poultry Science 81: 1548-1554.

Purves W. K., Sadava D., Orians G. H., Heller H. C. (2003): Life: The Science of Biology ( $7^{\text {th }}$ edition).Sunderland, Sinauer Associates and W. H. Freeman, 954 p.

Puthpongsiriporn U., Scheideler S. E., Shell J. L., Beck M. M. (2001): Effect of vitamin E and C supplementation on performance, in vitro lymphocyte proliferation, and antioxidant status of laying hens during heat stress. Poultry Science 80: 1190-1200.

Rael L. T., Thomas G. W., Craun M. L., Curtis C. G., Bar-Or R., Bar-Or D. (2004): Lipid peroxidation and the thiobarbituric acid assay: standardization of the assay when using saturated and unsaturated fatty acids. Journal of Biochemistry and Molecular Biology 37: 749-752.

Rey A. I., Segura J., Olivares A., Cerisuelo A., Piñeiro C., López-Bote C. J. (2015): Effect of micellized natural (D- $\alpha$-tocopherol) vs. synthetic (DL- $\alpha$-tocopheryl acetate) vitamin $\mathrm{E}$ supplementation given to turkeys on oxidative status and breast meat quality characteristics. Poultry Science 94: 1259-1269.

Roch G., Boulianne M., De Roth L. (2000): Effects of dietary vitamin $\mathrm{E}$ and selenium source on incidence of ascites, growth performance and blood parameters cold-stressed broilers. Poultry Science 79: Suppl. 1, 41.

Sahin K., Kucuk O. (2001): Effects of vitamin E and selenium on performance, digestibility of nutrients, and carcass characteristics of Japanese quails reared under heat stress $\left(34^{\circ} \mathrm{C}\right)$. Journal of Animal Physiology and Animal Nutrition 85: 342-348.
Sihvo H. K., Immonen K., Puolanne E. (2013): Myodegeneration with fibrosis and regeneration in the pectoralis major muscle of broilers. Veterinary Pathology 51: 619-623.

Surai P. F. (2002): Effect of selenium and vitamin E content of the maternal diet on the antioxidant system of the yolk and the developing chick. British Poultry Science 41: 235-243.

Surai P. F., Dvorska J. E. (2002): Effects of selenium and vitamin $\mathrm{E}$ content of the diet on lipid peroxidation in breast muscle tissue of broiler breeder hens during storage. Proceedings of Australian Poultry Science Symposium 14: 187-192.

Tayeb I. T., Qader G. K. (2012): Effect of feed supplementation of selenium and vitamin e on production performance and some hematological parameters of Broiler. KSU Journal of Natural Science 15: 46-56.

Villar P. G., Diaz C. A., Avila G. E., Guinzberg R., Pablos J. L., Pina E. (2002): Effects of dietary Supplementation with vitamin C or vitamin E on growth performance in broilers. American Journal of Veterinary Research 63: 573-576.

Voljc M., Frankic T., Levart A., Nemec M., Salobir J. (2011): Evaluation of different vitamin $\mathrm{E}$ recommendations and bioactivity of $\alpha$-tocopherol isomers in broiler nutrition by measuring oxidative stress in vivo and the oxidative stability of meat. Poultry Science 90: 1478-1488.

Wang Y. X., Zhan X. A., Zhang X. W., Wu R. J., Yuan D. (2011): Comparison of different forms of dietary selenium supplementation on growth performance, meat quality, selenium deposition, and antioxidant property in broilers. Biological Trace Element Research 143: 261-273.

Yoon I., Werner T. M., Butler J. M. (2007): Effect of source and concentration of selenium on growth performance and selenium retention in broiler chickens. Poultry Science 86: 727-730.

Young J. F., Stagsted J., Jensen S. K., Karlsson A. H., Henckel P. (2003): Ascorbic acid, alpha-tocopherol, and oregano supplements reduce stress-induced deterioration of chicken meat quality. Poultry Science 82: 1343-1351.

Received: August 19, 2020 Accepted after revisions: February 11, 2021 